\title{
CHLORIMURON-ETHYL IN CONVENTIONAL AND TRANSGENIC SOYBEAN CULTIVARS UNDER WATER DEFICIT STRESS ${ }^{1}$
}

\author{
CLEBSON GOMES GONÇALVES ${ }^{2 *}$, ANTONIO CARLOS DA SILVA JUNIOR ${ }^{3}$, MAYNUMI SCARANO $^{3}$, MARIA \\ RENATA ROCHA PEREIRA ${ }^{4}$, DAGOBERTO MARTINS ${ }^{3}$
}

\begin{abstract}
Water deficit is a limiting factor for the soybean yield; it triggers different physiological and anatomical adaptations that have deleterious effects on the plants and can affect the selectivity of herbicides, causing production losses. In this context, the objective of this work was to evaluate the action of the chlorimuron-ethyl herbicide when applied at different stages of soybean plants, using conventional and transgenic cultivars, and different soil water potentials. A rate of $20 \mathrm{~g} \mathrm{ha}^{-1}$ of the chlorimuron-ethyl herbicide was applied to two soybean cultivars (MG/BR46-Conquista - conventional, and BRS-Valiosa-RR - transgenic) at two phenological stages (V2 - first fully expanded trifoliate leaves, and V4 - third fully expanded trifoliate leaves), using three soil water potentials (-0.03 $\mathrm{MPa},-0.07 \mathrm{MPa}$, and $-0.5 \mathrm{MPa}$ ). Phytotoxicity, and plant height were evaluated at 3,7,14, and 21 days after the herbicide application. The shoot dry weight, root dry weight, and root system nodulation were evaluated. The soybean plants had lower phytotoxicity when subjected to application of chlorimuron-ethyl under water deficit conditions. The use of chlorimuron-ethyl reduced the growth and biomass of soybean plants and affected the plants' root system nodulation. The transgenic cultivar (BRS-Valiosa-RR) presented better performance when subjected to a moderate water deficit $(-0.07 \mathrm{MPa})$, which contributes to biological nitrogen fixation.
\end{abstract}

Keywords: Irrigation. ALS Inhibiting herbicide. Phytotoxicity. Glycine max. Selectivity.

\section{PULVERIZAÇÃO DE CHLORIMURON-ETHYL EM CULTIVARES DE SOJA CONVENCIONAL E TRANSGÊNICA SOB DIFERENTES MANEJOS HÍDRICOS}

RESUMO - O déficit hídrico é um fator limitante, pois desencadeiam diferentes adaptações fisiológicas e anatômicas que tem efeitos deletérios nas plantas o que pode afetar a seletividade dos herbicidas e ocasionar perdas às culturas agrícolas. $\mathrm{O}$ objetivo deste trabalho foi avaliar a ação do herbicida chlorimuron-ethyl, pulverizado em diferentes estádios de desenvolvimento da soja, cultivar convencional e transgênica, sob diferentes manejos de água no solo. A dose de $20 \mathrm{~g}$ i.a. ha ${ }^{-1}$ do herbicida chlorimuron-ethyl foi aplicada em dois estádios fenológico (V2-primeiro trifólio aberto e V4-terceiro trifólio aberto) de duas cultivares de soja: MG/BR 46 Conquista (convencional) e BRS Valiosa (RR), sob três condições hídricas no solo (-0,03; -0,07 e $0,5 \mathrm{MPa}$ ). Avaliou-se a fitointoxicação e altura de plantas aos 3, 7, 14 e 21 dias após a aplicação do herbicida. Ao final do estudo, determinou-se a massa seca da parte aérea, massa seca das raízes e nodulação do sistema radicular por meio do número e massa seca de nódulos. Constatou-se que, em condição de déficit hídrico as plantas de soja apresentaram uma menor fitotoxicidade visual quando submetida à pulverização do herbicida chlorimuron-ethyl. Além disso, o uso do herbicida chlorimuron-ethyl reduziu o crescimento e a biomassa das plantas de soja, afetando também a nodulação da cultura. A cultivar transgênica BRS Valiosa RR mostrou um melhor desempenho quando submetida a uma condição de escassez hídrica moderada $(-0,07 \mathrm{MPa})$ para sustentar a fixação biológica de nitrogênio.

Palavras-chave: Déficit hídrico. Inibidor da ALS. Fitointoxicação. Glycine max. Seletividade.

\footnotetext{
${ }^{*}$ Corresponding author

${ }^{1}$ Received for publication in $03 / 21 / 2017$; accepted in 05/17/2018.

${ }^{2}$ Department of Crop, Soil and Environmental Sciences, Auburn University, Auburn, AL, United States; goncalvescg.agro@hotmail.com ORCID: 0000-0001-8595-1646.

${ }^{3}$ Department of Crop Production, Universidade Estadual Paulista "Júlio de Mesquita Filho", Jaboticabal, SP, Brazil; acsjr_agro@hotmail.com - 0000-0002-9931-7686, maynumi.c.scarano@hotmail.com - 0000-0001-6070-2707, dagoberto.martins@unesp.br-ORCID: 0000-0002-2346-9667.
}

${ }^{4}$ Faculdade de Tecnologia de Capão Bonito, Capão Bonito, SP, Brazil; mariarenatarp@hotmail.com - 0000-0001-8023-2562.

Rev. Caatinga, Mossoró, v. 31, n. 4, p. 832 - 842, out. - dez., 2018 


\section{INTRODUCTION}

Soybean (Glycine max (L.) Merrill) is the most important legume in the world; it has been increasingly grown in Brazil in recent decades. However, the water requirement for this crop is high, and soybean plants have low water use efficiency (YANG; GQ LI; WU, 2003).

Therefore, water deficit is a limiting factor for this crop, especially considering the predominance of crop systems without irrigation in Brazil. This causes risks to the production, since occurrences of prolonged droughts during the crop season and offseason periods have been increasingly frequent (BALARDIN et al., 2011).

Soil water deficit causes imbalance between root water absorption and leaf transpiration. In addition, plants trigger different physiological adaptations that have deleterious effects-metabolic impairment of the photosynthetic apparatus, oxidative damages, hormonal changes, and accumulation of stress-related proteins-which interrupt cellular and molecular physiological and biochemical processes (SILVA et al., 2010; ASHRAF; HARRIS, 2013; GALMÉS et al., 2013). Plants have anatomical modifications that are specific adaptive processes to water stress, such as reductions in stomatal density, number of leaves, leaf expansion, xylem diameter, and parenchymal cell diameter, alterations in architecture, xylem to phloem ratio, and increase in vascular tissue and cell wall thickness (GUERFEL et al., 2009; MAKBUL et al., 2011; TRIPATHI et al., 2016; GONÇALVES et al., 2017).

Biological nitrogen fixation (BNF) contributes to increasing soybean crop production (HUNGRIA et al., 2006; HUNGRIA; MENDES, 2015), however, it is extremely sensitive to water deficit (CLEMENT et al., 2008; MASTRODOMENICO; PURCELL; KING, 2013).

The use of herbicides has become essential to agriculture because of the need of an adequate weed control for the crop development. Chlorimuron-ethyl is an herbicide of the sulfonylurea chemical group; it is widely used in soybean crops to control broadleaf weeds (TAN et al., 2013).

Herbicide selectivity allows controlling weeds without damaging the crop of interest. However, anatomical, physiological, and biochemical modifications due to abiotic stresses may affect plant characteristics (SILVA et al., 2010; GONÇALVES et al., 2017), increasing the sensitivity of the plants to an herbicide molecule.

Few studies have evaluated the effects of herbicides on soybean cultivars under water stress conditions, thus, the objective of this work was to evaluate the action of the chlorimuron-ethyl herbicide when applied at different stages of the soybean plants, using conventional and transgenic cultivars, and different soil water potentials.

\section{MATERIAL AND METHODS}

Two experiments were carried out in a greenhouse of the Plant Production Department of the Faculty of Agrarian Sciences and Veterinary of the São Paulo State University, (Jaboticabal campus), Brazil $\left(21^{\circ} 14^{\prime} 43.42^{\prime \prime} \mathrm{S}, 48^{\circ} 17^{\prime} 32.80^{\prime \prime} \mathrm{W}\right)$, in the $2014 / 2015$ crop season. The experimental units consisted of plastic pots containing $3 \mathrm{~kg}$ of soil. A composite sample of the soil was collected for chemical characterization before the experiment implementation. The soil chemical analysis showed $\mathrm{pH}(\mathrm{CaCl} 2)$ of $5.2,17 \mathrm{~g} \mathrm{dm}^{-3}$ of organic matter, 21 $\mathrm{mg} \mathrm{dm}{ }^{-3}$ of $\mathrm{P}, 8 \mathrm{mg} \mathrm{dm}^{-3}$ of S, $16 \mathrm{mmol} \mathrm{dm} \mathrm{m}^{-3}$ of $\mathrm{Ca}, 5$ $\mathrm{mmol} \mathrm{dm}{ }^{-3}$ of $\mathrm{Mg}, 2.3 \mathrm{mmol} \mathrm{dm}^{-3}$ of $\mathrm{K} ; 24 \mathrm{mmol} \mathrm{dm}$ ${ }^{3}$ of $\mathrm{H}+\mathrm{Al}$, sum of bases of $23.3 \mathrm{mmol} \mathrm{dm}^{-3}$, cation exchange capacity of 47.3 , and base saturation of $49 \%$. Liming and fertilization was carried out according to the recommendations for the crop.

Four soybean seeds were sown per pot. The seedlings were thinned, leaving only one plant per pot. The soil was previously irrigated to the field capacity for the seed germination process and seedling development.

The herbicide was applied at two phenological stages (V2 - first fully expanded trifoliate leaves, and V4 - third fully expanded trifoliate leaves) (FEHR; CAVINESS, 1977). A complete randomized experimental design was used, with four replications. Treatments were arranged in a $3 \times 2 \times 2$ factorial scheme, consisting of three soil water potentials $(-0.03 \mathrm{MPa},-0.07 \mathrm{MPa}$, and -0.5 $\mathrm{MPa}$ ), two soybean cultivars (MG/BR46-Conquista conventional, and BRS-Valiosa-RR - transgenic), and two application rates of chlorimuron-ethyl $(0 \mathrm{~g}$ $\mathrm{ha}^{-1}$ and $20 \mathrm{~g} \mathrm{ha}^{-1}$ ). Phytotoxicity evaluations were carried out using a $3 \times 2$ factorial scheme, considering only the plants subjected to herbicide application, since plants with no herbicide application were only used as control to compare the plant symptoms.

The soybean seeds were inoculated with Bradyrhizobium japonicum SEMIA 5079, and Bradyrhizobium elkanii SEMIA 5019 strains $\left(9 \times 10^{9}\right.$ viable cells per kilo of seeds) before seeding.

A soil sample was air dried to a moisture of $3 \%$ before the experiment implementation to obtain the soil water retention curve, using a Richards pressure plate (KLAR, 1984). Based on the water retention curve, three minimum soil water potentials were established: $-0.03 \mathrm{MPa},-0.07 \mathrm{MPa}$, and -0.5 $\mathrm{MPa}$ (soil water saturation of $13 \%, 10 \%$ and $9 \%$, respectively); they were determined by weighing the pots. When the weight reached the defined soil water potential for each treatment, the water lost by evapotranspiration was replenished until reaching the maximum soil water potential again: $-0.01 \mathrm{MPa}$ 
$(14 \%)$.

The herbicide was applied using a $\mathrm{CO}_{2-}$ pressurized backpack sprayer equipped with two XR110.02VS (Teejet $\AA$, Wheaton, USA) flat jet nozzles spaced $0.50 \mathrm{~m}$ apart, with a flow rate of 200 $\mathrm{L} \mathrm{ha}^{-1}$.

Phytotoxicity and plant height were evaluated at $3,7,14$, and 21 days after applying the herbicide (DAA). A grading scale was used to evaluate the phytotoxicity, with $0 \%$ representing absence of injuries, and $100 \%$ representing dead plants (GAZZIERO; VELINI; OSIPE, 1995).

Shoot and root dry weights of plants of each plot, and the plants' root system nodulation were evaluated at 21 DAA. The plants were dried in a forced-air circulation oven at $60{ }^{\circ} \mathrm{C}$ until constant weigh and weighed on a precision balance. The roots were carefully separated from the soil and washed in running water and their nodules were removed for evaluation; they were counted and dried in a forcedair circulation oven at $60{ }^{\circ} \mathrm{C}$ to determine their dry weight.

The data were subjected to analysis of variance by the $\mathrm{F}$ test and the means of the treatments were subjected to the Tukey test $(p>0.05)$.

\section{RESULTS AND DISCUSSION}

The phytotoxicity level caused using the chlorimuron-ethyl herbicide was low when it was applied at the V2 phenological stage of the soybean plants of the two cultivars evaluated (Table 1). The transgenic cultivar (BRS-Valiosa-RR) presented greater injuries in the evaluations at 3 , and 7 DAA than the conventional cultivar (MG/BR46Conquista), however, it showed a rapid recovery, since its injuries were smaller at 14 , and 21 DAA, compared to the conventional cultivar.

The plants grown in soil water deficit conditions $(-0.07 \mathrm{MPa}$, and $-0.5 \mathrm{MPa})$ presented lower phytotoxicity levels caused by chlorimuronethyl when compared to plants grown without water deficit $(-0.03 \mathrm{MPa})$ (Table 1). When the conventional cultivar was grown with no water stress $(-0.03 \mathrm{MPa})$ or with a slight water deficit $(-0.07$ $\mathrm{MPa})$, it presented higher phytotoxicity levels to chlorimuron-ethyl at 14 , and 21 DAA than the transgenic cultivar (Table 1). However, under severe water deficit $(-0.5 \mathrm{MPa})$, these differences were no longer found.

Table 1. Phytotoxicity of chlorimuron-ethyl to soybean plants at the V2 phenological stage, depending on the cultivar, soil water potential, and their interaction.

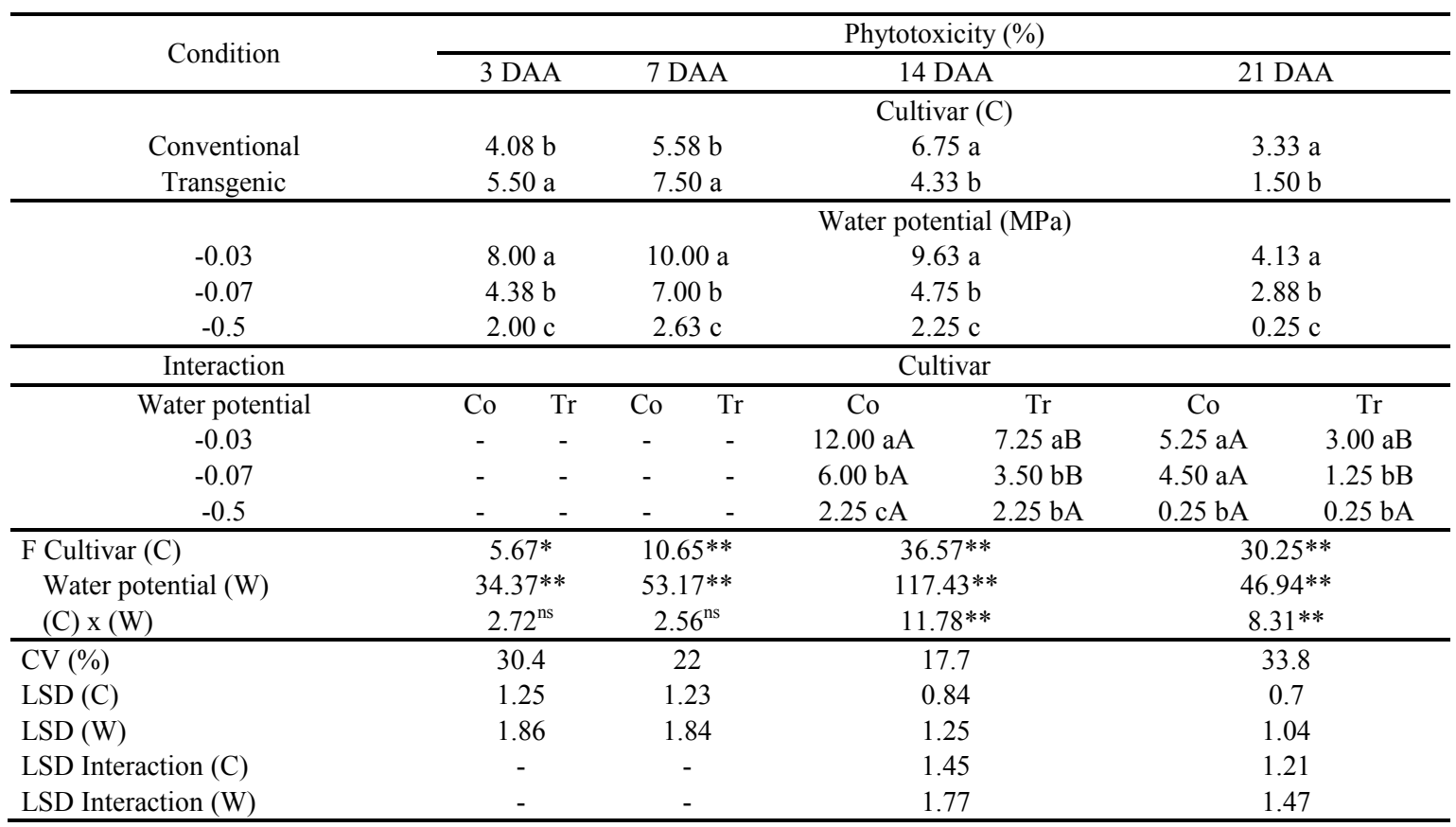

$* *=$ Significant at $1 \%$ probability level; $*=$ Significant at the $5 \%$ probability level; ns $=$ Not significant. Means followed by the same lowercase letter in the column and uppercase letter in the row were statistically similar by the Tukey test $(p<0.05)$. DAA $=$ days after application; $\mathrm{Tr}=$ transgenic; $\mathrm{Co}=$ Conventional; $\mathrm{CV}=$ Coefficient of variation; $\mathrm{LSD}=$ least significant difference.

The use of chlorimuron-ethyl herbicide at the V4 phenological stage caused low phytotoxicity levels in the soybean cultivars (Table 2), with the highest injury levels at $7 \mathrm{DAA}$, and mean of $12.17 \%$ for the conventional and $12.33 \%$ for the transgenic cultivar. When the herbicide was used in V2 (Table $1)$, the highest phytotoxicity levels were found in soybean plants grown with no water stress $(-0.03 \mathrm{MPa})$. 
The low phytotoxicity to chlorimuron-ethyl found in plants under water deficits $(-0.07 \mathrm{MPa}$, and $-0.5 \mathrm{MPa})$ may be due to several factors: their smaller leaf area, anatomical modifications of their leaves, and their higher cuticle and cell wall thickness, which result in lower absorption of the herbicide. These characteristics have been reported in studies as adaptive processes in response to soil water deficit (KUTLU et al., 2009; POLIZEL et al., 2011; GALMÉS et al., 2013).

Table 2. Phytotoxicity of chlorimuron-ethyl to soybean plants at the V4 phenological stage, depending on the cultivar, soil water potential, and their interaction.

\begin{tabular}{|c|c|c|c|c|c|c|c|}
\hline \multirow{2}{*}{ Condition } & \multicolumn{7}{|c|}{ Phytotoxicity (\%) } \\
\hline & \multicolumn{2}{|c|}{3 DAA } & $7 \mathrm{DAA}$ & \multicolumn{2}{|c|}{$14 \mathrm{DAA}$} & \multicolumn{2}{|c|}{$21 \mathrm{DAA}$} \\
\hline & \multicolumn{7}{|c|}{ Cultivar (C) } \\
\hline Conventional & \multirow{2}{*}{\multicolumn{2}{|c|}{$5.83 \mathrm{a}$}} & $12.17 \mathrm{a}$ & \multicolumn{2}{|c|}{$10.33 \mathrm{a}$} & \multicolumn{2}{|c|}{$5.00 \mathrm{~b}$} \\
\hline Transgenic & $4.17 \mathrm{~b}$ & & $12.33 \mathrm{a}$ & \multicolumn{2}{|c|}{$11.33 \mathrm{a}$} & \multicolumn{2}{|c|}{$6.50 \mathrm{a}$} \\
\hline & \multirow{2}{*}{\multicolumn{2}{|c|}{$9.13 \mathrm{a}$}} & \multicolumn{5}{|c|}{ Water potential (MPa) } \\
\hline-0.03 & & & & \multicolumn{2}{|c|}{$18.38 \mathrm{a}$} & \multicolumn{2}{|c|}{$11.00 \mathrm{a}$} \\
\hline-0.07 & \multicolumn{2}{|c|}{$4.88 \mathrm{~b}$} & $13.25 \mathrm{~b}$ & \multicolumn{2}{|c|}{$11.38 \mathrm{~b}$} & \multicolumn{2}{|c|}{$5.25 \mathrm{~b}$} \\
\hline-0.5 & \multicolumn{2}{|c|}{$1.00 \mathrm{c}$} & $6.88 \mathrm{c}$ & \multicolumn{2}{|c|}{$2.75 \mathrm{c}$} & \multicolumn{2}{|c|}{$1.00 \mathrm{c}$} \\
\hline Interaction & \multicolumn{7}{|c|}{ Cultivar } \\
\hline Water potential & $\mathrm{Co}$ & $\mathrm{Tr}$ & $\mathrm{Co}$ & $\mathrm{Tr} \quad \mathrm{Co}$ & $\operatorname{Tr}$ & $\mathrm{Co}$ & $\operatorname{Tr}$ \\
\hline-0.03 & - & - & - & $-18.50 \mathrm{aA}$ & $18.25 \mathrm{aA}$ & $11.00 \mathrm{aA}$ & $11.00 \mathrm{aA}$ \\
\hline-0.07 & - & - & - & - $\quad 9.00 \mathrm{bB}$ & $13.75 \mathrm{bA}$ & $3.00 \mathrm{bB}$ & $7.50 \mathrm{bA}$ \\
\hline-0.5 & - & - & - & $3.50 \mathrm{cA}$ & $2.00 \mathrm{cA}$ & $1.00 \mathrm{cA}$ & $1.00 \mathrm{cA}$ \\
\hline F Cultivar $(\mathrm{C})$ & 5.94 & & $0.03^{\mathrm{ns}}$ & & $6^{\mathrm{ns}}$ & 5.5 & $7 *$ \\
\hline Water potential $(\mathrm{W})$ & 47.09 & & $40.58^{* *}$ & 143 & $43^{* *}$ & 98.0 & $3 * *$ \\
\hline (C) $x(W)$ & 1.17 & & $1.15^{\mathrm{ns}}$ & & $0 * *$ & 6.5 & $7 * *$ \\
\hline $\mathrm{CV}(\%)$ & 33.5 & & 17.9 & & .1 & 24 & .9 \\
\hline $\operatorname{LSD}(\mathrm{C})$ & 1.44 & & 1.88 & & 58 & 1.2 & 23 \\
\hline $\operatorname{LSD}(\mathrm{W})$ & 2.14 & & 2.81 & & 36 & 1.8 & 83 \\
\hline LSD Interaction (C) & - & & - & & 74 & 2. & 13 \\
\hline LSD Interaction (W) & - & & - & & 34 & 2. & 59 \\
\hline
\end{tabular}

$* *=$ Significant at $1 \%$ probability level $; *=$ Significant at the $5 \%$ probability level; ns $=$ Not significant. Means followed by the same lowercase letter in the column and uppercase letter in the row were statistically similar by the Tukey test $(p<0.05)$. DAA $=$ days after application; $\mathrm{Tr}=$ transgenic $; \mathrm{Co}=$ Conventional $; \mathrm{CV}=$ Coefficient of variation; $\mathrm{LSD}=$ least significant difference.

In general, the plant height of the conventional and transgenic cultivars presented no difference at V2 (Table 3). However, the soil water restriction decreased the plant growth; the use of soil water potentials of $-0.07 \mathrm{MPa}$ and $-0.5 \mathrm{MPa}$ reduced significantly the plant height in all evaluation periods.

The lowest growth rates were observed in the plants subjected to water deficits of $-0.5 \mathrm{MPa}$. Several studies reported that plants reduce their growth and leaf area under water deficit as a response to water loss by photorespiration (LIU; JENSEN; ANDERSEN, 2003; MAK et al., 2014; GONÇALVES et al., 2017).

The application of chlorimuron-ethyl decreased the plant height of the soybean cultivars at 14 , and $21 \mathrm{DAA}$, compared to the control without herbicide application (Table 3 ).

The plants of the soybean cultivars had similar height at V2 and V4 (Table 3), with no differences found during the evaluations at 7, 14, and 21 DAA (Table 4). Soil water deficit reduced plant growth; the plants under water deficit of $-0.5 \mathrm{MPa}$ were the most affected.
Water deficit reduces plant growth by decreasing the water content in plant tissues, causing low turgidity pressure in the cells, affecting cell division, enlargement, and differentiation (JALEEL et al., 2008; SHAO et al., 2008).

The application of chlorimuron-ethyl at V4 decreased the plant height of the soybean cultivars at 7, 14, and 21 DAA when compared to the control without herbicide application (Table 4).

The reduction in plant growth after the chlorimuron-ethyl application occurred mainly in plants under adequate soil water conditions (-0.03 $\mathrm{MPa}$ ) (Table 5), with decreases in internode length. Plants under severe water restriction $(-0.5 \mathrm{MPa})$ were not affected by the chlorimuron-ethyl application.

Plants grown with no water stress probably can absorb more easily the chlorimuron-ethyl herbicide because this environmental condition allows a rapid plant growth and generate a higher activity of the herbicide in the plants, affecting their growth and development. Chlorimuron-ethyl is an acetolactate synthase (ALS) inhibiting herbicide, and this enzyme is necessary for the biosynthesis of 
valine and isoleucine (RAY, 1984; RAY, 1986); and the inhibition of this enzyme causes a rapid inhibition of cell division and plant growth (RAY, 1982).

Plants of the conventional cultivar had lower shoot dry weight (SDW) in V4 than those of the transgenic cultivar (Table 6). However, their root dry weight (RDW) was different-higher in the conventional cultivar. This was probably due to the genetic characteristics of the cultivars.

Table 3. Height of soybean plants subjected to chlorimuron-ethyl application at the V2 phenological stage, depending on the cultivar, soil water potential, and their interaction.

\begin{tabular}{|c|c|c|c|c|}
\hline \multirow{2}{*}{ Condition } & \multicolumn{4}{|c|}{ Plant Height $(\mathrm{cm})$} \\
\hline & $3 \mathrm{DAA}$ & $7 \mathrm{DAA}$ & 14 DAA & $21 \mathrm{DAA}$ \\
\hline & \multicolumn{4}{|c|}{ Cultivar (C) } \\
\hline Conventional & $10.52 \mathrm{a}$ & $11.79 \mathrm{a}$ & $14.85 \mathrm{a}$ & $17.27 \mathrm{a}$ \\
\hline Transgenic & $10.38 \mathrm{a}$ & $11.92 \mathrm{a}$ & $15.23 \mathrm{a}$ & $17.92 \mathrm{a}$ \\
\hline & \multicolumn{4}{|c|}{ Water potential $(\mathrm{MPa})$} \\
\hline-0.03 & $11.22 \mathrm{a}$ & $13.13 \mathrm{a}$ & $18.03 \mathrm{a}$ & $22.72 \mathrm{a}$ \\
\hline-0.07 & $10.34 \mathrm{~b}$ & $12.16 \mathrm{~b}$ & $15.34 \mathrm{~b}$ & $17.59 \mathrm{~b}$ \\
\hline-0.5 & $9.78 \mathrm{~b}$ & $10.28 \mathrm{c}$ & $11.75 \mathrm{c}$ & $12.47 \mathrm{c}$ \\
\hline & \multicolumn{4}{|c|}{ Herbicide Application $(\mathrm{H})$} \\
\hline Yes & $10.27 \mathrm{a}$ & $11.67 \mathrm{a}$ & $14.63 \mathrm{~b}$ & $16.94 \mathrm{~b}$ \\
\hline No & $10.63 \mathrm{a}$ & $12.04 \mathrm{a}$ & $15.46 \mathrm{a}$ & $18.25 \mathrm{a}$ \\
\hline F Cultivar $(\mathrm{C})$ & $0.37^{\mathrm{ns}}$ & $0.20^{\mathrm{ns}}$ & $1.17^{\mathrm{ns}}$ & $2.11^{\mathrm{ns}}$ \\
\hline Water potential $(\mathrm{W})$ & $12.18^{* *}$ & $35.67 * *$ & $110.02^{* *}$ & $176.82 * *$ \\
\hline Herbicide Application $(\mathrm{H})$ & $2.18^{\mathrm{ns}}$ & $1.80^{\mathrm{ns}}$ & $5.77 *$ & $8.70 * *$ \\
\hline$(\mathrm{C}) \mathrm{x}(\mathrm{W})$ & $0.76^{\mathrm{ns}}$ & $0.05^{\mathrm{ns}}$ & $1.05^{\mathrm{ns}}$ & $1.09^{\mathrm{ns}}$ \\
\hline (C) $x(\mathrm{H})$ & $2.18^{\mathrm{ns}}$ & $1.80^{\mathrm{ns}}$ & $0.13^{\mathrm{ns}}$ & $1.16^{\mathrm{ns}}$ \\
\hline$(\mathrm{W}) \times(\mathrm{H})$ & $2.29^{\mathrm{ns}}$ & $1.22^{\mathrm{ns}}$ & $0.72^{\text {ns }}$ & $2.63^{\mathrm{ns}}$ \\
\hline (C) $\mathrm{x}(\mathrm{W}) \mathrm{x}(\mathrm{H})$ & $2.21^{\mathrm{ns}}$ & $1.02^{\mathrm{ns}}$ & $1.31^{\mathrm{ns}}$ & $0.14^{\mathrm{ns}}$ \\
\hline $\mathrm{CV}(\%)$ & 8 & 8.2 & 8 & 8.8 \\
\hline $\operatorname{LSD}(\mathrm{C}) /(\mathrm{H})$ & 0.49 & 0.57 & 0.7 & 0.9 \\
\hline $\operatorname{LSD}(\mathrm{W})$ & 0.72 & 0.84 & 1.04 & 1.33 \\
\hline
\end{tabular}

$* *=$ Significant at $1 \%$ probability level; $*=$ Significant at the $5 \%$ probability level; ns $=$ Not significant. Means followed by the same letter in the column were statistically similar by the Tukey test $(p<0.05)$. DAA $=$ days after application; $\mathrm{CV}=$ Coefficient of variation; $\mathrm{LSD}=$ least significant difference.

Table 4. Height of soybean plants subjected to chlorimuron-ethyl application at the V4 phenological stage, depending on the cultivar, soil water potential, and the use of the herbicide. Jaboticabal, São Paulo, Brazil, 2015.

\begin{tabular}{|c|c|c|c|c|}
\hline \multirow{2}{*}{ Condition } & \multicolumn{4}{|c|}{ Plant Height $(\mathrm{cm})$} \\
\hline & 3 DAA & 7 DAA & 14 DAA & 21 DAA \\
\hline & \multicolumn{4}{|c|}{ Cultivar } \\
\hline Conventional & $15.73 \mathrm{~b}$ & $17.94 \mathrm{a}$ & $21.56 \mathrm{a}$ & $27.13 \mathrm{a}$ \\
\hline \multirow[t]{2}{*}{ Transgenic } & $16.71 \mathrm{a}$ & $18.85 \mathrm{a}$ & $22.10 \mathrm{a}$ & $27.65 \mathrm{a}$ \\
\hline & \multicolumn{4}{|c|}{ Water potential $(\mathrm{MPa})$} \\
\hline-0.03 & $18.91 \mathrm{a}$ & $21.50 \mathrm{a}$ & $26.00 \mathrm{a}$ & $33.41 \mathrm{a}$ \\
\hline-0.07 & $16.41 \mathrm{~b}$ & $19.16 \mathrm{~b}$ & $23.13 \mathrm{~b}$ & $28.63 \mathrm{~b}$ \\
\hline \multirow[t]{2}{*}{-0.5} & $13.34 \mathrm{c}$ & $14.93 \mathrm{c}$ & $16.38 \mathrm{c}$ & $20.13 \mathrm{c}$ \\
\hline & \multicolumn{4}{|c|}{ Herbicide Application } \\
\hline Yes & $15.79 \mathrm{a}$ & $17.42 \mathrm{~b}$ & $20.13 \mathrm{~b}$ & $24.59 \mathrm{~b}$ \\
\hline No & $16.65 \mathrm{a}$ & $19.28 \mathrm{a}$ & $23.54 \mathrm{a}$ & $30.19 \mathrm{a}$ \\
\hline F Cultivar (C) & $4.36^{*}$ & $2.92^{\text {ns }}$ & $0.56^{\mathrm{ns}}$ & $0.54^{\mathrm{ns}}$ \\
\hline Water potential (W) & $47.03^{* *}$ & $58.18^{* *}$ & $62.32 * *$ & $122.68 * *$ \\
\hline Herbicide Application $(\mathrm{H})$ & $3.31^{\mathrm{ns}}$ & $13.31 * *$ & $22.35 * *$ & $63.68 * *$ \\
\hline$(\mathrm{C}) \times(\mathrm{W})$ & $0.39^{\mathrm{ns}}$ & $0.46^{\mathrm{ns}}$ & $0.44^{\mathrm{ns}}$ & $2.09^{\mathrm{ns}}$ \\
\hline (C) $\times(\mathrm{H})$ & $0.05^{\mathrm{ns}}$ & $0.02^{\mathrm{ns}}$ & $1.20^{\mathrm{ns}}$ & $0.46^{\mathrm{ns}}$ \\
\hline$(\mathrm{W}) \times(\mathrm{H})$ & $1.52^{\mathrm{ns}}$ & $4.27 *$ & $8.78 * *$ & $17.56^{* *}$ \\
\hline (C) $\times(W) \times(H)$ & $0.48^{\mathrm{ns}}$ & $0.46^{\mathrm{ns}}$ & $1.65^{\mathrm{ns}}$ & $2.61^{\mathrm{ns}}$ \\
\hline CV (\%) & 10 & 8.2 & 11.5 & 8.9 \\
\hline $\operatorname{LSD}(\mathrm{C}) /(\mathrm{H})$ & 0.95 & 1.09 & 1.47 & 1.42 \\
\hline $\operatorname{LSD}(\mathrm{W})$ & 1.40 & 1.61 & 2.16 & 2.10 \\
\hline
\end{tabular}

$* *=$ Significant at $1 \%$ probability level; $*=$ Significant at the $5 \%$ probability level; ns $=$ Not significant. Means followed by the same letter in the column were statistically similar by the Tukey test $(p<0.05)$. DAA $=$ days after application; $\mathrm{CV}=$ Coefficient of variation; $\mathrm{LSD}=$ least significant difference. 
C. G. GONÇALVES et al.

Table 5. Height of soybean plants subjected to chlorimuron-ethyl application at the V4 phenological stage, depending on the interaction between soil water potential and use of chlorimuron-ethyl herbicide.

\begin{tabular}{|c|c|c|c|c|c|c|c|c|}
\hline \multirow{2}{*}{ Interaction } & \multicolumn{8}{|c|}{ Plant Height $(\mathrm{cm})$} \\
\hline & \multicolumn{2}{|c|}{3 DAA } & \multicolumn{2}{|c|}{$7 \mathrm{DAA}$} & \multicolumn{2}{|c|}{ 14 DAA } & \multicolumn{2}{|c|}{$21 \mathrm{DAA}$} \\
\hline \multirow{2}{*}{ Water potential } & \multicolumn{8}{|c|}{ Herbicide Application } \\
\hline & Yes & No & Yes & No & Yes & No & Yes & No \\
\hline-0.03 & - & - & $19.50 \mathrm{aB}$ & $23.50 \mathrm{aA}$ & $22.19 \mathrm{aB}$ & $29.81 \mathrm{aA}$ & $27.81 \mathrm{aB}$ & $39.00 \mathrm{aA}$ \\
\hline-0.07 & - & - & $19.06 \mathrm{aA}$ & $19.25 \mathrm{bA}$ & $22.13 \mathrm{aA}$ & $24.13 \mathrm{bA}$ & $26.44 \mathrm{aB}$ & $30.81 \mathrm{bA}$ \\
\hline-0.5 & - & - & $13.69 \mathrm{bA}$ & $15.38 \mathrm{cA}$ & $16.06 \mathrm{bA}$ & $16.69 \mathrm{cA}$ & $19.51 \mathrm{bA}$ & $20.75 \mathrm{cA}$ \\
\hline LSD (Row) & \multicolumn{2}{|c|}{-} & \multicolumn{2}{|c|}{1.89} & \multicolumn{2}{|c|}{2.54} & \multicolumn{2}{|c|}{2.46} \\
\hline LSD (Column) & \multicolumn{2}{|c|}{ - } & \multicolumn{2}{|c|}{2.27} & \multicolumn{2}{|c|}{3.06} & \multicolumn{2}{|c|}{2.96} \\
\hline
\end{tabular}

Means followed by the same lowercase letter in the column and uppercase letter in the row were statistically similar by the Tukey test $(p<0.05)$. DAA $=$ days after application; $\mathrm{LSD}=$ least significant difference.

The soil water deficit reduced the shoot and root biomass in both soybean phenological stages (Table 6). The moderate water deficit $(-0.07 \mathrm{MPa})$ reduced $40.1 \%$ of the SDW, and $31.0 \%$ of the RDW in $\mathrm{V} 2$; and $44.2 \%(\mathrm{SDW})$, and $55.9 \%$ (RDW) in $\mathrm{V} 4$ (Table 6). This reduction was even more pronounced in plants under water deficit of $-0.5 \mathrm{MPa}$.
Roots of soybean cultivars that are tolerant to water deficit manifest physiological and morphological alterations to provide a normal plant growth and improve their ability to respond to drought stress (LIUQING et al., 2016). Moreover, these genotypes have relatively higher photosynthetic capacity and more robust antioxidative defense system (YU et al., 2016).

Table 6. Shoot dry weight (SDW) and root dry weight (RDW) of soybean plants subjected to chlorimuron-ethyl application at the V2 and V4 phenological stages, depending on the cultivar, soil water potential, and the use of the herbicide.

\begin{tabular}{|c|c|c|c|c|}
\hline \multirow{3}{*}{ Condition } & \multicolumn{4}{|c|}{ Phenological stage } \\
\hline & \multicolumn{2}{|c|}{ V2 } & \multicolumn{2}{|c|}{ V4 } \\
\hline & $\mathrm{SDW}(\mathrm{g})$ & RDW (g) & SDW (g) & RDW (g) \\
\hline & \multicolumn{4}{|c|}{ Cultivar (C) } \\
\hline Conventional & $0.86 \mathrm{a}$ & $0.39 \mathrm{a}$ & $2.45 \mathrm{~b}$ & $1.21 \mathrm{a}$ \\
\hline Transgenic & $0.91 \mathrm{a}$ & $0.39 \mathrm{a}$ & $2.96 \mathrm{a}$ & $1.02 \mathrm{~b}$ \\
\hline & \multicolumn{4}{|c|}{ Water potential $(\mathrm{MPa})(\mathrm{W})$} \\
\hline-0.03 & $1.42 \mathrm{a}$ & $0.58 \mathrm{a}$ & $4.66 \mathrm{a}$ & $2.09 \mathrm{a}$ \\
\hline-0.07 & $0.85 \mathrm{~b}$ & $0.40 \mathrm{~b}$ & $2.60 \mathrm{~b}$ & $0.92 \mathrm{~b}$ \\
\hline-0.5 & $0.38 \mathrm{c}$ & $0.19 \mathrm{c}$ & $0.86 \mathrm{c}$ & $0.34 \mathrm{c}$ \\
\hline & \multicolumn{4}{|c|}{ Herbicide Application $(\mathrm{H})$} \\
\hline Yes & $0.78 \mathrm{~b}$ & $0.35 \mathrm{~b}$ & $2.49 \mathrm{~b}$ & $2.84 \mathrm{~b}$ \\
\hline No & $0.99 \mathrm{a}$ & $0.43 \mathrm{a}$ & $2.92 \mathrm{a}$ & $1.39 \mathrm{a}$ \\
\hline F Cultivar (C) & $0.31^{\mathrm{ns}}$ & $0.01^{\mathrm{ns}}$ & $23.36 * *$ & $9.45^{* *}$ \\
\hline Water potential (W) & $54.85^{* *}$ & $62.04 * *$ & $434.84 * *$ & $275.80 * *$ \\
\hline Herbicide Application $(\mathrm{H})$ & $7.21 *$ & $7.63 * *$ & $16.66 * *$ & $78.56^{* *}$ \\
\hline (C) $x(W)$ & $0.30^{\mathrm{ns}}$ & $0.31^{\mathrm{ns}}$ & $4.94 *$ & $15.78^{* *}$ \\
\hline (C) $x(\mathrm{H})$ & $2.04^{\mathrm{ns}}$ & $1.07^{\mathrm{ns}}$ & $2.73^{\mathrm{ns}}$ & $32.49^{* *}$ \\
\hline$(\mathrm{W}) \times(\mathrm{H})$ & $3.23^{\mathrm{ns}}$ & $3.48 *$ & $6.75 * *$ & $48.50 * *$ \\
\hline$(\mathrm{C}) \times(\mathrm{W}) \times(\mathrm{H})$ & $0.11^{\mathrm{ns}}$ & $0.03^{\mathrm{ns}}$ & $1.34^{\mathrm{ns}}$ & $19.01 * *$ \\
\hline CV $(\%)$ & 31.7 & 25.6 & 13.5 & 19.3 \\
\hline $\operatorname{LSD}(\mathrm{C}) /(\mathrm{H})$ & 0.16 & 0.06 & 0.21 & 0.13 \\
\hline $\operatorname{LSD}(\mathrm{W})$ & 0.24 & 0.09 & 0.31 & 0.19 \\
\hline
\end{tabular}

$* *=$ Significant at $1 \%$ probability level; $*=$ Significant at the $5 \%$ probability level; $\mathrm{ns}=$ Not significant. Means followed by the same letter in the column were statistically similar by the Tukey test $(p<0.05)$. CV $=$ Coefficient of variation; $\mathrm{LSD}=$ least significant difference.

The use of chlorimuron-ethyl herbicide at V2 and V4 reduced the SDW and RDW of the soybean plants (Table 6).

The conventional cultivar grown with no water stress (-0.03 and $-0.07 \mathrm{MPa})$ had lower SDW than the transgenic cultivar at V4 (Table 7). However, the SDW of both cultivars were similarly affected by the water deficit of - $0.5 \mathrm{MPa}$.

The conventional cultivar had higher RDW than the transgenic cultivar when grown with no water stress $(-0.03 \mathrm{MPa})$ (Table 7$)$. The cultivars presented no differences when grown under water deficit conditions 
Table 7. Shoot dry weight (SDW) and root dry weight (RDW) of soybean plants subjected to chlorimuron-ethyl application at the V2 and V4 phenological stages, depending on the interactions between the cultivar, soil water potential, and the use of herbicide.

\begin{tabular}{|c|c|c|c|c|c|c|c|c|}
\hline \multirow{3}{*}{ Interaction } & \multicolumn{8}{|c|}{ Phenological stage } \\
\hline & \multicolumn{4}{|c|}{$\mathrm{V} 2$} & \multicolumn{4}{|c|}{ V4 } \\
\hline & \multicolumn{2}{|c|}{ SDW $(g)$} & \multicolumn{2}{|c|}{ RDW (g) } & \multicolumn{2}{|c|}{$\mathrm{SDW}(\mathrm{g})$} & \multicolumn{2}{|c|}{ RDW (g) } \\
\hline \multirow[b]{2}{*}{ Water potential (MPa) } & \multicolumn{8}{|c|}{ Cultivar } \\
\hline & Co & $\operatorname{Tr}$ & Co & $\operatorname{Tr}$ & Co & $\operatorname{Tr}$ & Co & $\operatorname{Tr}$ \\
\hline-0.03 & - & - & - & - & $4.28 \mathrm{aB}$ & $5.04 \mathrm{aA}$ & $2.43 \mathrm{aA}$ & $1.75 \mathrm{aB}$ \\
\hline-0.07 & - & - & - & - & $2.23 \mathrm{bB}$ & $2.96 \mathrm{bA}$ & $0.86 \mathrm{bA}$ & $0.99 \mathrm{bA}$ \\
\hline-0.5 & - & - & - & - & $0.84 \mathrm{cA}$ & $0.88 \mathrm{cA}$ & $0.35 \mathrm{cA}$ & $0.32 \mathrm{cA}$ \\
\hline LSD (Row) & - & & & . & & 45 & & 26 \\
\hline LSD (Column) & - & & & . & & 37 & & 22 \\
\hline \multirow{2}{*}{ Cultivar } & \multicolumn{8}{|c|}{ Herbicide Application } \\
\hline & Yes & No & Yes & No & Yes & No & Yes & No \\
\hline Conventional & - & - & - & - & - & - & $0.76 \mathrm{aB}$ & $1.66 \mathrm{aA}$ \\
\hline Transgenic & - & - & - & - & - & - & $0.92 \mathrm{aB}$ & $1.12 \mathrm{bA}$ \\
\hline LSD (Row)/(Column) & & & & & & & & 18 \\
\hline \multirow{2}{*}{ Water potential } & \multicolumn{8}{|c|}{ Herbicide Application } \\
\hline & Yes & No & Yes & No & Yes & No & Yes & No \\
\hline-0.03 & - & - & $0.49 \mathrm{aB}$ & $0.68 \mathrm{aA}$ & $4.17 \mathrm{aB}$ & $5.14 \mathrm{aA}$ & $1.39 \mathrm{aB}$ & $2.80 \mathrm{aA}$ \\
\hline-0.07 & - & - & $0.38 \mathrm{aA}$ & $0.43 \mathrm{bA}$ & $2.48 \mathrm{bA}$ & $2.71 \mathrm{bA}$ & $0.81 \mathrm{bB}$ & $1.04 \mathrm{bA}$ \\
\hline-0.5 & - & - & $0.18 \mathrm{bA}$ & $0.19 \mathrm{cA}$ & $0.82 \mathrm{cA}$ & $0.91 \mathrm{cA}$ & $0.33 \mathrm{cA}$ & $0.35 \mathrm{cA}$ \\
\hline LSD (Row) & - & & & 02 & & 37 & & \\
\hline LSD (Column) & - & & & 22 & & 45 & & 26 \\
\hline
\end{tabular}

Means followed by the same lowercase letter in the column and uppercase letter in the row were statistically similar by the Tukey test $(p<0.05)$. DAA $=$ days after application; $\mathrm{Tr}=$ transgenic $; \mathrm{Co}=$ Conventional; $\mathrm{LSD}=$ least significant difference.

The use of chlorimuron-ethyl at V2 affected the RDW of soybean plants grown with no water stress (-0.03 $\mathrm{MPa})$ (Table 7). The herbicide application at $\mathrm{V} 4$ affected the plants grown under moderate water deficit $(-0.07 \mathrm{MPa})$.

The SDW of plants grown with no water stress $(-0.03 \mathrm{MPa})$ reduced at V4 due to the use of chlorimuron-ethyl; whereas plants under water deficit conditions present no reduction in SDW.

The conventional cultivar had greater biological nitrogen fixation than the transgenic cultivar at V2 (Table 8), since it exhibited a higher number of nodules (NN) and nodule dry weight (NDW). However, the NN and NDW were higher for the transgenic plants at V4.

The infection of the soybean plants by the rhizobia was sensitive to the soil water deficit, inhibiting $100 \%$ of infection by rhizobia at V2 (Table 8). Plants grown with no water stress $(-0.03$ $\mathrm{MPa}$ ) presented normal infection by rhizobia. These results were due to the water deficits at early stages of plant development, at the beginning of root nodulation by nitrogen-fixing bacteria (RYLE; POWELL; GORDON, 1979).

The NN and NDW of plants under soil water deficit of -0.07 and $-0.5 \mathrm{MPa}$ presented great reductions in $\mathrm{V} 4$, which are similar results to those found in plants at V2 phenological stage. NDW is used to evaluate the efficiency of the biological nitrogen fixation in soybean plants (SOUZA et al.,
2008).

The use of chlorimuron-ethyl negatively affected rhizobia infection (Table 8); the $\mathrm{NN}$ and NDW of plants reduced at V2 and V4, compared to control without herbicide application.

Post-emergent herbicide application for weed management are usually carried out when the phenological stage of the soybean plants is between V2 and V4, mainly due to the growth stage of the weeds. The chlorimuron-ethyl herbicide has good selectivity for soybean crops, however, it may affect the productive performance of the plants because of the nitrogen requirements of this crop is mainly supplied by atmospheric $\mathrm{N}_{2}$ through biological fixation.

According to the interaction between cultivar and soil water potential in plants grown with no water stress $(-0.03 \mathrm{MPa})$ at $\mathrm{V} 2$ stage, the conventional cultivar had higher NN and NDW than the transgenic cultivar (Table 9).

The cultivars presented no differences in NN and NDW at V4 when grown with no water stress (-0.03 MPa) (Table 9). However, the conventional cultivar had a greater reduction in NN and NDW when grown under moderate water deficit $(-0.07 \mathrm{MPa})$ than the transgenic cultivar. This denotes the greater effect of the infection by the rhizobia on the transgenic cultivar when grown under moderate water deficit conditions. 
Table 8. Number of nodules (NN), and nodule dry weight (NDW) of soybean plants subjected to chlorimuron-ethyl application at the V2 and V4 phenological stages, depending on the cultivar, soil water potential, and the use of herbicide.

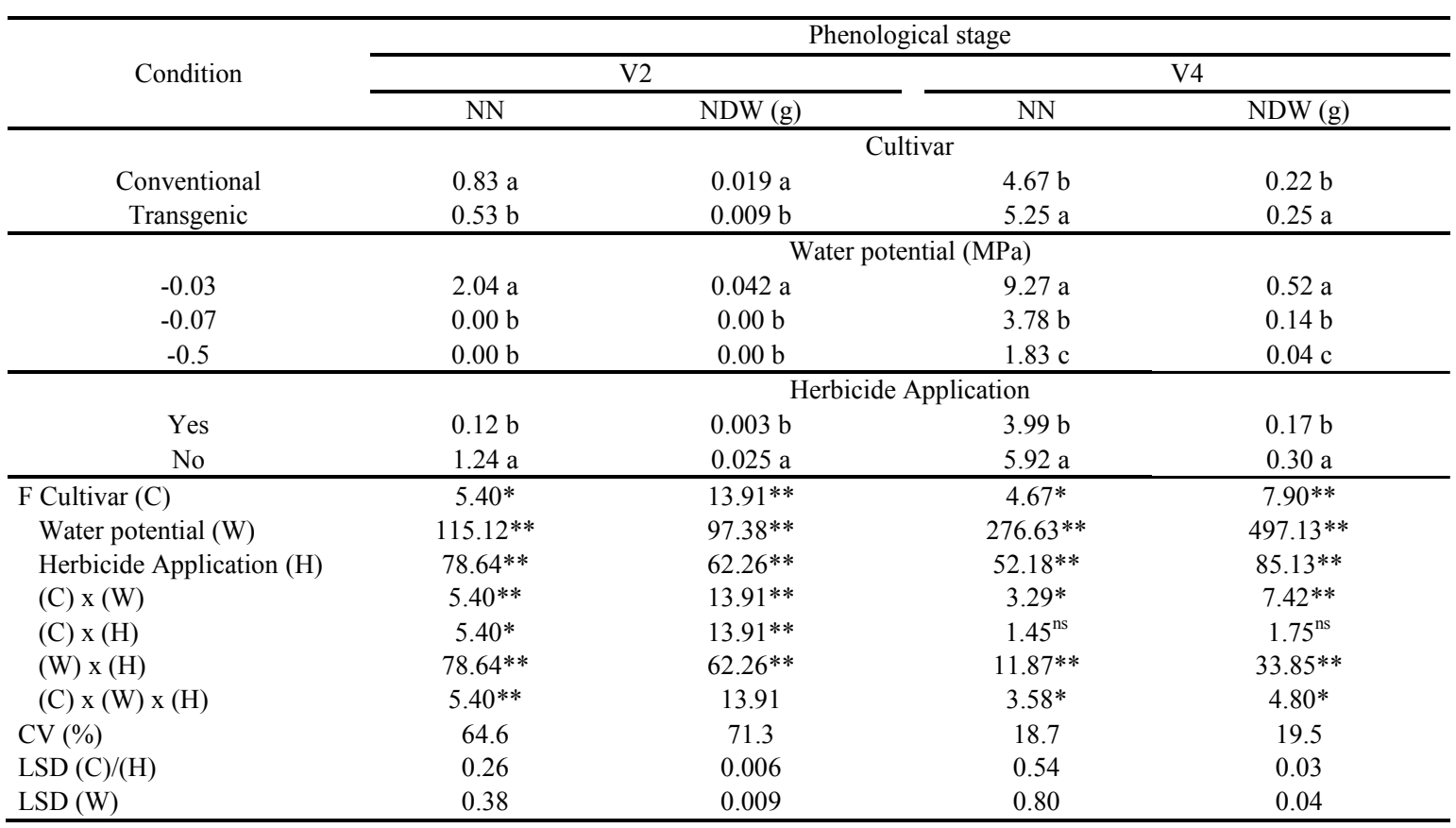

$* *=$ Significant at $1 \%$ probability level; $*=$ Significant at the $5 \%$ probability level; ns $=$ Not significant. Means followed by the same letter in the column were statistically similar by the Tukey test $(p<0.05)$. CV $=$ Coefficient of variation; LSD $=$ least significant difference. Data transformed by the equation $y=\sqrt{x}$.

Table 9. Number of nodules (NN), and nodule dry weight (NDW) of soybean plants subjected to chlorimuron-ethyl application at the V2 and V4 phenological stages, depending on the interactions between cultivar, soil water potential, and the use of herbicide.

\begin{tabular}{|c|c|c|c|c|c|c|c|c|}
\hline \multirow{3}{*}{ Interaction } & \multicolumn{8}{|c|}{ Phenological stage } \\
\hline & \multicolumn{4}{|c|}{ V2 } & \multicolumn{4}{|c|}{$\mathrm{V} 4$} \\
\hline & \multicolumn{2}{|c|}{$\mathrm{NN}$} & \multicolumn{2}{|c|}{ NDW (g) } & \multicolumn{2}{|c|}{$\mathrm{NN}$} & \multicolumn{2}{|c|}{ NDW (g) } \\
\hline & \multicolumn{8}{|c|}{ Cultivar } \\
\hline Water potential $(\mathrm{MPa})$ & Co & $\operatorname{Tr}$ & Co & $\operatorname{Tr}$ & Co & $\operatorname{Tr}$ & Co & $\operatorname{Tr}$ \\
\hline-0.03 & $2.48 \mathrm{aA}$ & $1.60 \mathrm{aB}$ & $0.06 \mathrm{aA}$ & $0.03 \mathrm{aB}$ & $9.23 \mathrm{aA}$ & $9.30 \mathrm{aA}$ & $0.52 \mathrm{aA}$ & $0.52 \mathrm{aA}$ \\
\hline-0.07 & $0.00 \mathrm{bA}$ & $0.00 \mathrm{bA}$ & $0.00 \mathrm{bA}$ & $0.00 \mathrm{bA}$ & $3.00 \mathrm{bB}$ & $4.55 \mathrm{bA}$ & $0.09 \mathrm{bB}$ & $0.20 \mathrm{bA}$ \\
\hline-0.5 & $0.00 \mathrm{bA}$ & $0.00 \mathrm{bA}$ & $0.00 \mathrm{bA}$ & $\underline{0.00 \mathrm{bA}}$ & $1.78 \mathrm{cA}$ & $1.88 \mathrm{cA}$ & $0.04 \mathrm{bA}$ & $0.04 \mathrm{cA}$ \\
\hline$\overline{\mathrm{LSD}} \overline{\mathrm{S}}(\overline{\mathrm{Row}} \overline{\mathrm{s}} \overline{-}-\overline{-}$ & & & & & & $\overline{13}---$ & $--\overline{0}$ & \\
\hline LSD (Column) & & & & & & 94 & & \\
\hline \multirow{2}{*}{ Cultivar } & \multicolumn{8}{|c|}{ Herbicide Application } \\
\hline & Yes & No & Yes & No & Yes & No & Yes & No \\
\hline Conventional & $0.12 \mathrm{aB}$ & $1.54 \mathrm{aA}$ & $0.003 \mathrm{aB}$ & $0.04 \mathrm{aA}$ & - & - & - & - \\
\hline Transgenic & $0.12 \mathrm{aB}$ & $0.95 \mathrm{bA}$ & $0.003 \mathrm{aB}$ & $\underline{0.01 \mathrm{bA}}$ & - & - & - & \\
\hline$\overline{\mathrm{LSD}}(\mathrm{Row}) /($ Column $)$ & & & & & & & & \\
\hline \multirow{2}{*}{ Water potential } & \multicolumn{8}{|c|}{ Herbicide Application } \\
\hline & Yes & No & Yes & No & Yes & No & Yes & No \\
\hline-0.03 & $0.35 \mathrm{aB}$ & $3.72 \mathrm{aA}$ & $0.008 \mathrm{aB}$ & $0.076 \mathrm{aA}$ & $7.76 \mathrm{aB}$ & $10.77 \mathrm{aA}$ & $0.39 \mathrm{aB}$ & $0.66 \mathrm{aA}$ \\
\hline-0.07 & $0.00 \mathrm{aA}$ & $0.00 \mathrm{bA}$ & $0.00 \mathrm{aA}$ & $0.00 \mathrm{bA}$ & $2.44 \mathrm{bB}$ & $5.12 \mathrm{bA}$ & $0.09 \mathrm{bB}$ & $0.19 \mathrm{bA}$ \\
\hline-0.5 & $0.00 \mathrm{aA}$ & $0.00 \mathrm{bA}$ & $0.00 \mathrm{aA}$ & $0.00 \mathrm{bA}$ & $1.78 \mathrm{bA}$ & $1.88 \mathrm{cA}$ & $0.04 \mathrm{cA}$ & $0.04 \mathrm{cA}$ \\
\hline LSD (Row) & \multicolumn{2}{|c|}{0.45} & \multicolumn{2}{|c|}{0.01} & \multicolumn{2}{|c|}{0.94} & \multicolumn{2}{|c|}{0.046} \\
\hline LSD (Column) & \multicolumn{2}{|c|}{0.54} & \multicolumn{2}{|c|}{0.01} & \multicolumn{2}{|c|}{1.13} & \multicolumn{2}{|c|}{0.056} \\
\hline
\end{tabular}

** = Significant at $1 \%$ probability level; $*=$ Significant at the $5 \%$ probability level; ns $=$ Not significant. Means followed by the same lowercase letter in the column and uppercase letter in the row were statistically similar by the Tukey test $(p<0.05) . \mathrm{CV}=$ Coefficient of variation; LSD $=$ least significant difference. Data transformed by the equation $y=\sqrt{ } x$. 
Studies report differences in the ability of soybean genotypes to maintain biological nitrogen fixation under soil water deficit conditions (CHEN et al., 2007; SINCLAIR et al., 2007). The maintenance of the survival of the rhizobia may be related to the expression of genes that encode proteins involved in the response to water deficit (MARINO; GONZÁLEZ; ARRESE-IGOR, 2006; CLEMENT et al., 2008).

According to the interaction between soil water potential and use of herbicide, the $\mathrm{NN}$ and NDW of the plants grown under adequate water conditions (-0.03 $\mathrm{MPa})$ with chlorimuron-ethyl application decreased at V2 (Table 9). This result was also found in V4 for plants grown under adequate soil water conditions and moderate water deficit (-0.03 $\mathrm{MPa}$ and $-0.07 \mathrm{MPa})$.

The chlorimuron-ethyl herbicide has been widely used in the last decades to control weeds in soybean crops. However, frequent application of chlorimuron-ethyl can seriously disturb communities of nitrogen-fixing bacteria, altering their structure (ZHANG et al., 2013). No studies describing direct effects of this herbicide on biological nitrogen fixation are found. Therefore, further studies must be carried out to assess the factors related to these effects and possible strategies for their reduction.

\section{CONCLUSIONS}

The phytotoxicity of the herbicide chlorimuron-ethyl herbicide to soybean plants is lower under soil water deficit conditions. The use of this herbicide reduces the growth and biomass of soybean plants and affect their root system nodulation. The transgenic cultivar BRS-Valiosa-RR has better performance when subjected to a moderate water deficit condition $(-0.07 \mathrm{MPa})$, which contributes to biological nitrogen fixation.

\section{ACKNOWLEDGEMENTS}

The authors thank the Coordination for the Improvement of Higher Education Personnel (CAPES) for granting a scholarship to the first author.

\section{REFERENCES}

ASHRAF, M.; HARRIS, P. J. C. Photosynthesis under stressful environments: an overview. Photosynthetica, Prague, v. 51, n. 2, p. 163-190, 2013.

BALARDIN, R. S. et al. Tratamento de sementes com fungicidas e inseticidas como redutores dos efeitos do estresse hídrico em plantas de soja. Ciência Rural, Santa Maria, v. 41, n. 7, p. 11201126, 2011.

CHEN, P. et al. Registration of soybean germplasm lines R01-416F and R01-581F for improved yield and nitrogen fixation under drought stress. Journal of Plant Registrations, Madison, v. 1, n. 2, p. 166167, 2007.

CLEMENT, M. et al. Identification of new upregulated genes under drought stress in soybean nodules. Gene, Amsterdam, v. 426, n. 1, p. 15-22, 2008 .

FEHR, W. R.; CAVINESS, C. E. Stages of soybean development. Ames: State University of Science and Technology, 1977. 11 p. (Special report, 80).

GAZZIERO, D. L. P.; VELINI, E. D.; OSIPE, R. Procedimentos para instalação, avaliação e análise de experimentos com herbicidas. Londrina, PR: Sociedade Brasileira da Ciência das Plantas Daninhas, 1995. 42 p.

GALMÉS, J. et al. Leaf responses to drought stress in Mediterranean accessions of Solanum lycopersicum: anatomical adaptations in relation to gas exchange parameters. Plant, Cell \& Environment, Chichester, v. 36, n. 5, p. 920-935, 2013.

GONÇALVES, C. G. et al. Morphological modifications in soybean in response to soil water management. Plant Growth Regulation, Dordrecht, v. 83, n. 1, p. 105-117, 2017.

GUERFEL, M. et al. Impacts of water stress on gas exchange, water relations, chlorophyll content and leaf structure in the two main Tunisian olive (Olea europaea L.) cultivars. Scientia Horticulturae, Amsterdam, v. 119, n. 3, p. 257-263, 2009.

HUNGRIA, M. et al. Nitrogen nutrition of soybean in Brazil: Contributions of biological $\mathrm{N}_{2}$ fixation and $\mathrm{N}$ fertilizer to grain yield. Canadian Journal of Plant Science, Ottawa, v. 86, n. 4, p. 927-939, 2006.

HUNGRIA, M.; MENDES, I. C. Nitrogen Fixation with Soybean: The Perfect Symbiosis? In: DE BRUIJN, F. J. (Ed.). Biological Nitrogen Fixation. Wiley-Blackwell, New Jersey, 2015. v. 2, chap. 99, p. 1005-1019.

JALEEL, C. A. et al. Alterations in morphological parameters and photosynthetic pigment responses of Catharanthus roseus under soil water deficits. Colloids and Surfaces B: Biointerfaces, Amsterdam, v. 61, n. 2, p. 298-303, 2008. 
KLAR, A. E. Evapotranspiração. In: KLAR, A. E. A água no sistema solo-planta-atmosfera. 2 . ed. São Paulo, SP: Nobel, 1984. 408 p.

KUTLU, N. et al. Changes in anatomical structure and levels of endogenous phytohormones during leaf rolling in Ctenanthe setosa under drought stress. Turkish Journal of Biology, Ankara, v. 33, n. 2, p. 115-122, 2009.

LIU, F.; JENSEN, C. R.; ANDERSEN, M. N. Hydraulic and chemical signals in the control of leaf expansion and stomatal conductance in soybean exposed to drought stress. Functional Plant Biology, Clayton, v. 30, n. 1, p. 65-73, 2003.

LIUQING, Y. et al. Effects of drought stress on physiological property and growth parameter of different drought resistance soybean cultivars. Journal of Agricultural Science and Technology, Beijing, v. 18, n. 2, p. 115-120, 2016.

MARINO, D.; GONZÁLEZ, E. M.; ARRESEIGOR, C. Drought effects on carbon and nitrogen metabolism of pea nodules can be mimicked by paraquat: evidence for the occurrence of two regulation pathways under oxidative stresses. Journal of Experimental Botany, Oxford, v. 57, n. 3, p. 665-673, 2006.

MAKBUL, S. et al. Changes in anatomical and physiological parameters of soybean under drought stress. Turkish Journal of Botany, Ankara, v. 35, n. 4, p. 369-377, 2011.

MASTRODOMENICO, A. T.; PURCELL, L. C.; $\mathrm{KING}, \mathrm{C}$. A. The response and recovery of nitrogen fixation activity in soybean to water deficit at different reproductive developmental stages. Environmental and Experimental Botany, Amsterdam, v. 85, n. 1, p. 16-21, 2013.

MAK, M. et al. Leaf mesophyll $\mathrm{K}^{+}, \mathrm{H}^{+}$and $\mathrm{Ca}^{2+}$ fluxes are involved in drought-induced decrease in photosynthesis and stomatal closure in soybean. Environmental and Experimental Botany, Amsterdam, v. 98, n. 1, p. 1-12, 2014.

POLIZEL, A. M. et al. Molecular, anatomical and physiological properties of a genetically modified soybean line transformed with rd29A: AtDREB1A for the improvement of drought tolerance. Genetics and Molecular Research, Ribeirão Preto, v. 10, n. 4, p. 3641-3656, 2011.

RAY, T. B. The mode of action of chlorsulfuron: a new herbicide for cereals. Pesticide Pesticide Biochemistry and Physiology, San Diego, v. 17, n. 1, p. 10-17, 1982.
RAY, T. B. Site of action of chlorsulfuron: inhibition of valine and isoleucine biosynthesis in plants. Plant physiology, Bethesda, v. 75, n. 3, p. 827-831, 1984.

RAY, T. B. Sulfonylurea herbicides as inhibitors of amino acid biosynthesis in plants. Trends in Biochemical Sciences, Amsterdam, v. 11, n. 4, p. 180-183, 1986.

RYLE, G. J. A.; POWELL, C. E.; GORDON, A. J. The Respiratory Costs of Nitrogen Fixation in Soyabean, Cowpea, and White Clover II. Comparisons of the cost of nitrogen fixation and the utilization of combined nitrogen. Journal of Experimental Botany, Oxford, v. 30, n. 1, p. 145 153,1979

SINCLAIR, T. R. et al. Drought tolerance and yield increase of soybean resulting from improved symbiotic N 2 fixation. Field Crops Research, Amsterdam, v. 101, n. 1, p. 68-71, 2007.

SILVA, C. D. S. et al. Curso diário das trocas gasosas em plantas de feijão-caupi submetidas a deficiência hídrica. Revista Caatinga, Mossoró, v. 23, n. 4, p. 7-13, 2010.

SHAO, H. B. et al. Higher plant antioxidants and redox signaling under environmental stresses. Comptes Rendus Biologies, Issy les Moulineaux, v. 331, n. 6, p. 433-441, 2008.

SOUZA, R. A. et al. Minimal set of parameters for evaluation soil microbiota and biological nitrogen fixation in soybean. Pesquisa Agropecuária Brasileira, Brasília, v. 43, n. 1, p. 83-91, 2008.

TAN, H. et al. Effects of chlorimuron-ethyl application with or without urea fertilization on soil ammonia-oxidizing bacteria and archaea. Journal of Hazardous Materials, Amsterdam, v. 260, n. 1, p. 368-374, 2013.

TRIPATHI, P. et al. A toolbox of genes, proteins, metabolites and promoters for improving drought tolerance in soybean includes the metabolite coumestrol and stomatal development genes. BMC Genomics, London, v. 17, n. 1, p. 1-22, 2016.

YANG, P. H.; GQ LI, G. L.; WU, S. J. Effect of drought stress on plasma membrane permeability of soybean varieties during flowering-poding stage. Agricultural Research In The Arid Areas, Xinxiang Yangling, v. 21, n. 1, p. 127-130, 2003.

YU, X. et al. A comparative proteomic study of drought-tolerant and drought-sensitive soybean seedlings under drought stress. Crop and Pasture Science, Clayton, v. 67, n. 5, p. 528-540, 2016. 
ZHANG, X. et al. Responses of soil nitrogen-fixing, ammonia-oxidizing, and denitrifying bacterial communities to long-term chlorimuron-ethyl stress in a continuously cropped soybean field in Northeast China. Annals of Microbiology, Heidelberg, v. 63, n. 4, p. 1619-1627, 2013. 